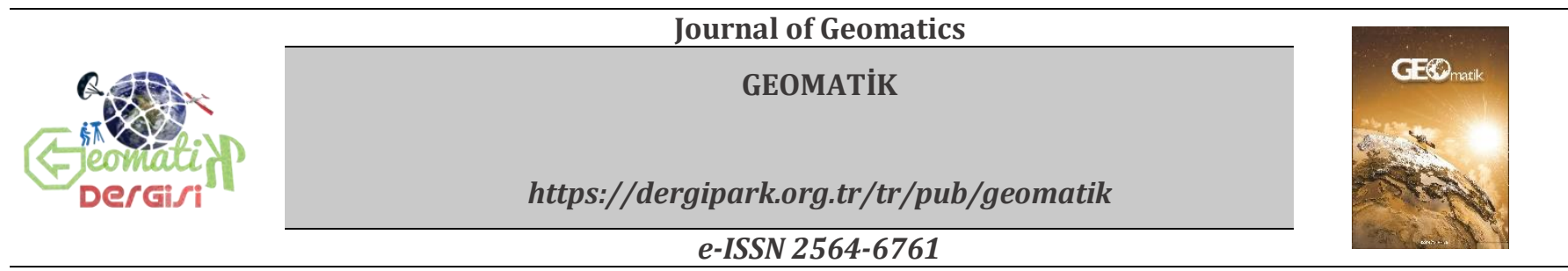

\title{
Hücresel otomata markov zincir yöntemi ile kentsel yayılmanın modellenmesi: Kerkük ili örneği
}

\author{
Abdullah Fadhil Tawfeeq*1(D), Tuba Kurban ${ }^{1}$ (D) \\ ${ }^{1}$ Erciyes Üniversitesi, Mühendislik Fakültesi, Harita Mühendisliği Bölümü, Kayseri, Türkiye
}

\author{
Anahtar Kelimeler \\ Arazi Kullanımı \\ Arazi Örtüsü \\ Kentsel Yayılma \\ Hücresel Otomata \\ Markov Zincir modeli
}

\begin{abstract}
ÖZ
Kentsel yayılma küresel bir olgudur ancak Irak gibi gelişmekte olan ülkelerde çok daha hızlı bir şekilde gerçekleşmektedir. Kerkük, kentsel alanlarda hızla artan bir genişlemeye tanık olunan Irak kentlerinden biridir. Bu kentsel yayılma; hızlı nüfus artıșı, plansız büyüme ve göç gibi çeşitli faktörlerden kaynaklanmaktadır. Bunun sonucunda kentsel ekosistem bu süreçten önemli ölçüde etkilenmektedir. Bu çalışmada, 2002-2018 yılları arasında Kerkük ilindeki arazi kullanımı/arazi örtüsü değișiklikleri CBS ve uzaktan algılama teknikleri kullanılarak incelenmiştir. Tespit edilen değișimler göstermektedir ki en büyük değișiklik \%130 oranında bir artıșla kentsel alanlarda gerçekleșmiștir. Bununla birlikte tarım arazilerinin \%22 ve su alanlarının da \%8 oranında genişlediği tespit edilmiştir. Buna karşılık, açık arazi alanında \%3 oranında bir azalma olduğu da görülmüştür. Bu aşamadan sonra, gelecekte yaşanacak kentsel yayılma oranının öngörülmesi amaciyla karma bir Hücresel Otomata Markov Zincir modeli oluşturulmuştur. Model mevcut arazi kullanım haritası ile karşılaştırılmıştır ve Kappa istatistikleri kullanılarak doğrulanmıștır. Kappa standart, kappa konum ve kappa nicelik katsayıları sırasıyla $0.8799,0.9143$ ve 0.9154 olarak bulunmuştur. Bu sonuçlar, referans haritası ile karşılaștırma haritası arasında iyi bir örtüşme olduğunu göstermektedir. Ayrıca bu model, 2030 ve 2035 yıllarında gerçekleşmesi muhtemel kentsel yayılmanın tahmin edilmesi için kullanılmıştır.
\end{abstract}

\section{Modelling urban sprawl with cellular automata markov chain method: The case of Kirkuk governorate}

\author{
Keywords \\ Land Use \\ Land Cover \\ Urban Sprawl \\ Cellular Automata \\ Markov Chain Model.
}

\begin{abstract}
Urban sprawl is a global phenomenon, but it is happening much faster in developing countries such as Iraq. Kirkuk is one of the Iraqi cities that is witnessing a rapidly increasing expansion in urban areas. This urban sprawl is caused by various factors such as rapid population growth, unplanned growth and migration. As a result, the urban ecosystem is significantly affected by this process. In this study, land use/land cover changes in the Kirkuk between 2002-2018 were analyzed by using of GIS and remote sensing techniques. The results of change detection showed that the biggest change has occurred with an increase of $130 \%$. In addition, it was determined that agricultural lands expanded by $22 \%$ and water areas by $8 \%$. On the other hand, it was observed that there was a 3\% decrease in barren land areas. After this stage, an hybrid Cellular Automata Markov Chain model was built to predict the future urban sprawl rate. The model has been compared with the existing land use map and validated using the Kappa statistics. Kappa standard, kappa location and kappa no coefficients were found as $0.8799,0.9143$ and 0.9154 , respectively. These results show that there is a good agreement between the reference map and the comparison map. In addition, the created model has been used to predict the urban sprawl in 2030 and 2035.
\end{abstract}




\section{GíRiş}

Dünya'da ve özellikle de gelișmekte olan ülkelerde, kentsel alanlar bugüne dek benzeri görülmemiş bir hızla genişlemekte ve kentsel nüfus da benzer bir şekilde artış göstermektedir. Öyle ki, 2030 yılına kadar Dünya nüfusunun \%60'ının kentsel alanlarda yaşayacağı ve kentsel yayılmanın çoğunlukla daha az gelişmiş ülkelerde gerçekleșeceği öngörülmektedir (Forte, Cerreta, \& De Toro, 2019). Irak'ta da benzer bir durum söz konusudur. Kentsel yayılma ve gelişmenin hızla devam etmesi, Irak'ın 1987 yılında 16 milyon olan (Atşan, 2011) kentsel nüfusunun 2018 yılında 38 milyona yükselmesine neden olmuştur. Irak Planlama Bakanlığı, Irak nüfusunun, her yıl ortalama 850 bin - 1 milyon kişi aralığında bir artış gösterdiğini belirtmekte, 2025 ve 2030 yıllarında sirasiyla 45 milyona ve 51 milyona ulaşacağını öngörmektedir. Kerkük, bilhassa son yıllardaki savaş ortamı nedeniyle çevre kentlerden aşırı şekilde göç almaktadır ve bu nedenle nüfus yoğunluğunda önemli bir artış yașanmaktadır. $\mathrm{Bu}$ nedenle, arazi kullanımı ve arazi örtüsü değişikliklerinin büyüklüğünu, desenini ve türünü değerlendirmeye ve gelecekteki arazi gelişimini tahmin etmeye yönelik acil bir ihtiyaç hali söz konusudur.

Arazi kullanımı ve arazi örtüsü terimleri birbiriyle ilişkilidir. Arazi örtüsü, arazinin yüzeyini kaplayan doğal bitki örtüsünü de içeren toprak tabakasını, tarım ürünlerini ve insan yapılarını ifade eder. Arazi kullanımı ise bu kavramın tersine, arazi örtüsünden yararlanılması anlamına gelmekte olup, arazi yönetim uygulamalarını da içerir Ancak, bu iki terim yaygın olarak arazi kullanımı/arazi örtüsü şeklinde kullanılmaktadır (Sarı \& Özşahin, 2016).

Hızlı nüfus artışı, kentsel alanların sınırlarının kontrolsüz ve gelişigüzel bir şekilde büyümesine yol açmıştır ki bu durum genellikle, kara yolları boyunca ya da şehrin etrafındaki kırsal alana doğru genişleme olarak tanımlanan "kentsel yayılma" terimi ile açıklanmaktadır (Bugliarello, 2003). Kişi sayısının giderek artmasından dolayı bu bölgelerde yaşayanların sayısı sürekli değişmektedir ve kesin rakamı tahmin edilememektedir. Öyle ki, bu durum hızlı nüfus artışının başarılı bir şekilde yönetilemediğinin bir göstergesidir ve kent merkezlerinin plansız bir şekilde genişlemesine yol açmaktadır. Kentsel yayılma, çevresel etkileri kadar sosyal etkileri de olan karmaşık bir olgudur (Barnes, Morgan III, Roberge, \& Lowe, 2001). Bu karmaşıklıktan dolayı, kentsel yayılmanın spesifik, ölçülebilir ve genel olarak kabul edilmiş bir tanımı yoktur (Sutton, 2003) ancak gerçek nüfus birikim alanları sınırları dışında kalan bağlantılı bir büyüme durumu olarak tanımlanabilir ve bu yaklaşımın dünya genelinde görüldüğü büyük şehir sayısı giderek artmaktadır (Gordon \& Richardson, 1997). Kentsel yayılma; su, hava, gürültü ve katı atık kirliliğinin yanı sıra verimli tarım arazilerinin yok olmasına, açık yeşil alanların, yüzey su kütlelerinin ve yeraltı su kaynaklarının kaybına neden olmaktadır. Kentsel yayılmanın izlenmesi, çevresel ve doğal kaynakların kritik şekilde tehlike altında olduğu alanların belirlenmesine ve gelecekteki olası büyüme ve yayılma modellerinin oluşturulmasına yardımcı olmaktadır (Simmons, 2007).
Yine de arazi kullanım değişikliğinin etkili bir şekilde araştırılması, izlenmesi ve takip edilmesi için çalışma alanı hakkında hayli çok veri gereksinimi söz konusudur. $\mathrm{Bu}$ nedenle, uzaktan algılama teknolojisinin kullanımı, arazi kullanımının mekânsal değişikliğini verimli bir şekilde elde etmek, analiz etmek ve simüle etmek için kullanılabilecek güncellenmiş bir arazi kullanımı ve arazi örtüsü verileri sağlamaktadır (Dadhich \& Hanaoka, 2011), (Wakode, Baier, Jha, \& Azzam, 2014), (Youssef, Pradhan, \& Tarabees, 2011).

Uzaktan algılama amaçlı uydu sistemleri, coğrafi bilgi sistemleri (CBS) ile birlikte yaygın olarak kullanılmakta ve arazi kullanımı değișiminin tespit edilmesinde güçlü ve etkili bir araç olarak kabul görmektedir (Jadkowski, Howard, \& Brostuen, 1990), (Méaille \& Wald, 1990), (Harris \& Ventura, 1995). Bu sistemler ile elde edilen uygun maliyetli, çok bantlı (multispektral) ve çok zamanlı (multitemporal) veriler, arazi kullanımı ve arazi örtüsü veri kümelerini oluşturmakta ve gerekli olan anlamlı bilgilere dönüştürülmektedir. CBS teknolojisi, değişimin algılanması ve veritabanının geliştirilmesi için gerekli olan dijital verilerin depolanması, analiz edilmesi ve görüntülenmesi için esnek bir ortam sağlamaktadır. Uydu görüntülerinin sınıflandırılması ile arazi örtüsü tiplerinin izlenmesi ve takip edilmesi sağlanmakta ve spektral yansıtıcılar veya indekslerle doğrusal ilişkiler yoluyla arazi yüzeylerinin biyofiziksel özelliklerini tahmin edilmesi sağlanmaktadır (Steininger, 1996).

Kentsel arazi kullanım değişikliği modelleri; kentsel yayılmanın etkisinin değerlendirilmesi, arazi dönüşüm yönetimi, arazi kullanım planlarının hazırlanması, arazi kullanım değişikliklerinin optimum modellerinin tanımlanması ve kentsel planlayıcıların sürdürülebilir kentsel çevreye ulaşmasını sağlaması nedeniyle oldukça işlevsel ve yararlıdır. Arazi kullanımındaki değişikliğin modellenmesi ve simülasyon süreci her ne kadar karmaşık olsa da gerekli bir işlemdir (Yang, Zheng, \& Lv, 2012). Gelecekteki olası farklı koşullar için arazi kullanım değişikliğinin muhtemel senaryolarını simüle etmek, keşfetmek ve öngörebilmek için yararlanılan arazi kullanım modellerini üç kategoriye ayırarak incelemek mümkündür. $\mathrm{Bu}$ modeller; (a) lojistik regresyon, yapay sinir ağları, karar destek vektörleri ve derin öğrenme gibi makine öğrenmesi modelleri (Alsharif \& Pradhan, 2014; Arsanjani, Kainz, \& Mousivand, 2011); (b) Hücresel Otomata, Markov Zincirleri, SLEUTH gibi hücresel modeller (Al-shalabi, Billa, Pradhan, Mansor, \& Al-Sharif, 2013); (c) bahsedilen yöntemlerin kombinasyonlarını içeren Hücresel Otomata-Markov Zincir modeli, Yapay Sinir AğlarıMarkov Zincir modeli, Hücresel Otomata-Lojistik Regresyon, Vektörel Hücresel Otomata gibi karma modeller (Verburg et al., 2002) şeklinde ifade edilebilir.

Hücresel Otomata (CA) tahminleri, tarihi kentsel alanların farklı arazi kullanım türleri arasındaki etkileşimler yoluyla gelecekteki genişleme modellerini etkileyeceği varsayımıyla desteklenmektedir. Değişiklikleri önceden tanımlanmış koşullu kurallar altında tahsis ederken, CA her zaman en yüksek değişim olasılığına sahip hücrelerle başlar. Ancak, geleneksel CA yaklaşımı, kentsel genişleme itici güçlerinin rolünü nicel olarak dikkate almadan yalnızca mekansal tahsiste mahalle etkisini hesaba katar ve geçiş kuralları genellikle 
çok basittir. CA için bu sınırlamalar, yapay sinir ağları, lojistik regresyon ve Markov Zincir modeli (MC) gibi diğer modellerle entegre edilerek aşılabilir. Çeşitli olası kombinasyonlar arasında, CA-MC entegrasyonu en sık kullanılanlardan biri olmuştur çünkü bu teknik kapsamlı verileri gerektirmemekte, böylece az sayıda parametre ve fiziksel kısitlar ile kentsel yayılma modellenebilmesini sağlamaktadır (H. Wu et al., 2019; Xu, Gao, \& Coco, 2019).

Belirtmek gerekir ki, Markov Zincir modeli, coğrafyanın ilk kuralına dayanmaktadır, yani, kentsel arazi kullanım sınıfı yakın bir pikselin kentsel sınıf haline gelme olasılığı daha uzak bir pikselden daha fazladır. Markov Zincir modeli, belirli iki tarih aralığındaki zamansal dönemde arazi kullanımının değişme olasılığını belirlemek için oldukça etkili ve çok güçlü bir yöntemdir. Ancak, Markov Zincir modeli, arazi kullanım değişikliği olaylarının mekânsal dağılımını sağlayamamaktadır (Araya \& Cabral, 2010).

Entegre Hücresel Otomata Markov Zincir (CA-MC) modeli arazi kullanımı/arazi örtüsü değişim modellerinin nicelik tahmini ile mekansal ve zamansal dinamik modellemesi açısından elverişli ve sağlam bir tekniktir. Öyle ki, uzaktan algllama verileri ve CBS, arazi kullanımı/arazi örtüsü ile oldukça başarılı bir şekilde birleştirilerek kullanılabilir. Buna ek olarak, CA-MC, bir Hücresel Otomata fonksiyonu aracılığıyla, Markov Zincir modelinin sonuçlarını, kentsel planlama ve tasarım için gerekli, mekânsal olarak açık ve anlaşılır sonuçlara çevirebilir (Guan et al., 2011).

Bu çalışma son yirmi yıl boyunca çok hızlı ve dağınık bir kentsel yayılmanın görüldüğü Kerkük İli (Irak) üzerine gerçekleştirilen bir vaka çalışması niteliğindedir. 2002-2018 yılları arasındaki dönemi kapsayan süreçte, Kerkük şehrinde arazi kullanımı ve arazi örtüsü değișikliklerini analiz etmek için uzaktan algılama amaçlı Landsat uydu sistemleri ve ENVI, ArcGIS ve TerrSet tekniklerinden yararlanılmıştır. Ayrıca, 2030 ve 2035 yıllarındaki arazi kullanım değişikliklerini tahmin etmek için CA-MC modeli uygulanmıştır ve Kappa istatistiklerine göre başarılı sonuçlar elde edilmiştir.

\section{Kentsel Yayılma}

"Kentsel Yayılma" terimi ilk olarak 1937'de Güneydoğu ABD'deki ilk şehir planlamacılarından biri olan Earle Draper tarafından kullanılmıștır (Nechyba \& Walsh, 2004). Kirklı yılların sonlarında kentsel yayılmanın ulaşım ve gelirle bağlantıları karakterize eden ana temalar belirlenmiștir. 1961'de Jane Jacobs, "The Death and Life of Great American Cities" (Jacobs, 1961) adl eserinde Kuzey Amerika'da gelişmekte olan dağınık şehir modelinin verimsizliğine dikkat çekmiştir. $\mathrm{Bu}$ model, çok sayıda otomobili desteklemek için tasarlanmış otoyollara yapılan yoğun yatırımla birlikte gelişimin gerçekleştiği çevre ve dağınık yerleşim mahallelerinin tanitımına dayanmaktadir. Jacobs, olağanüstü bir açıklıkla, bu tür bir şehrin sosyal ve kültürel yaşamı nasıl yok ettiğini, daha az yaratıcı ve daha tehlikeli ortamlara yol açtığını açıklamaktadır. 1960'lardan günümüze, yayılmanın sinırlandırmaları, nedenleri ve sonuçlarına dair geniş bir literatür oluşmuştur.
Kentsel yayılma, birbiriyle ilişkili karmaşı sosyoekonomik ve kültürel parametrelerin bir sonucudur (Başlık, 2008). Bununla birlikte, arazi değeri, genellikle kalkınma modellerinin temel itici gücü olarak kabul edilir. Yayılma, kentsel merkezlerin çevresinde mülk değerlerinin daha düşük olduğu yerlerde ortaya çıkma eğilimindedir (Pendall, 1999). Ekonomistler, mekansal kentsel genişleme veya yayılma yaratmak için arazi değerleriyle etkileşime giren üç temel etken tanımlamaktadır. Kentsel alanların dışa doğru genişlemesine neden olan nüfus artışı, sakinlerin daha geniş bir yaşam alanı satın almalarına izin veren artan gelir ve ulaşım altyapısına yapılan geçmiş yatırımların ürettiği işe gidip gelme maliyetlerinin düşmesidir (Carruthers \& Ulfarsson, 2002).

Kentsel yayılma ile ilişkili çeşitli sosyal ve ekonomik sonuçları tanımlarken, bu makale çevre sorunlarına odaklanmaktadır. $\mathrm{Bu}$ olumsuz etkiler arasında, diğerlerinin yanı sıra, otomobil bağımlılı̆ından kaynaklanan hava kirliliği, kısmen geçirimsiz yüzeylerdeki artışlardan kaynaklanan su kirliliği, kritik doğal habitatlar gibi çevreye duyarlı alanların bozulması, açık alanlarda artan sel riskleri ve yaşam kalitesinde meydana gelen genel düşüşler sayılabilir (Kahn, 2000).

Arazi rekabetine katkıda bulunan önemli bir küresel eğilim, dağınık kentsel gelişimdir. 2008 yılından bu yana, gezegen nüfusunun yarısı şehirlerde ve yığınlarda yaşamaktadır ve bu oran artmaktadır (Avrupa Çevre Ajansı, 2006; Staff, Forschungsstelle, \& Centre, 2006).

\section{Kentsel Yayılım Simülasyon Yöntemleri}

Kentsel yayılma simülasyon yöntemleri temel olarak doğrusal regresyon (Seto, Fragkias, Güneralp, \& Reilly, 2011), analitik hiyerarşi süreci (AHP), sistem dinamikleri (SD), yapay zeka, yapay sinir ağları, lojistik regresyon (LR) gibi teknikleri içermektedir. Doğrusal regresyon, belirli bir regresyon analizi türüdür ve bağımsız ve bağımlı değişkenler arasındaki ilişkileri açıklar. AHP yöntemi birçok sosyo-ekonomik ve mühendislik uygulamalarında yaygın olarak kullanılmaktadır. Bununla birlikte, bağımlı değişkenler kategorik değişkenler veya mekansal özelliklere sahip değişkenler olduğunda iyi bir performans göstermemektedir. AHP, her faktöre atanan ağırlığı türetmek için uygun bir yöntemdir (Dai, Lee, \& Zhang, 2001). AHP ayrıca karar alternatiflerinin ikili karşılaştırma kullanılarak önceliklendirilmesine izin verir. Bununla birlikte, çok sayıda alternatif nedeniyle raster veriler için ikili karşılaştırma yapmak zordur (Ozturk \& Batuk, 2011). Ek olarak, AHP ne çok sayıda alternatifi değerlendirmede ne de performans sınırlarını seçmede etkili değildir (Wey, 2013).

SD modeli, özellikle sosyo-ekonomik itici güçlerin araştırılması ve karmaşık sistemlerin simülasyonu için uygun bir yöntemdir (X. Liu et al., 2017). Ayrıca, uzaysal dinamikleri dahil etmek için Hücresel Otomata yöntemi ile bağlanabilir, ancak yine de faktörleri ve etkilerini tanımlamada yetersiz kalmaktadır. Kentsel yayılmanın mekansal örüntü değişimini ortaya çıkarmada ve kentsel genişlemeyi etkileyen mekansal değişkenleri modellemeye dahil etmede dezavantajları vardır. 
Son zamanlarda uzaysal-zamansal modeller kullanılabilir hale gelmiștir. Uzaktan algılama, coğrafi bilgi sistemleri ve mekansal istatistiklerin entegrasyonu bu nedenle kentsel yayılmanın izlenmesi ve modellenmesi için güçlü bir yöntem oluşturmaktadır. $\mathrm{Bu}$ yöntemlerin gücü, kentsel genişlemedeki farklılıkları açıklarken mekansal ilişkileri hesaba katmalarıdır. (Osman, Arima, \& Divigalpitiya, 2016).

Yapay zeka algoritmaları, kentsel arazi kullanımını inceleme ve mekansal çeşitliliği ele alma konusunda oldukça yeteneklidir (Grekousis, Manetos, \& Photis, 2013). Yapay zeka teknikleri, mekansal-zamansal analiz, gelecekteki eğilimlerin tahmini ve kentsel bölgelerin gelişiminin tahmini için kullanılabilir (W. Liu \& Seto, 2008). Bununla birlikte, Sinir Ağı modellemesi daha fazla hesaplama kaynağı gerektirir (Tu, 1996). Bir sinir ağı modeli, lojistik regresyon modeline klyasla göreceli bir "kara kutudur" (Guerriere \& Detsky, 1991). Regresyon, ikili bağımlı ve birkaç bağımsız kategorik ve sürekli değişken arasındaki ilişkiyi belirleme yöntemidir (Verhagen, 2007). Lojistik regresyon, bağıml değişkenlerin regresyon problemlerini sürekli olmayan değișkenler olarak ele alabilir ve bu, bağımlı ve bağımsız değişkenler arasında doğrusal bir ilişki gerektirmez. CBS ile birleştirildiğinde, değișkenlerin mekansal özelliklerini etkili bir şekilde yansıtabilir ve belirgin güç analizi ve arazi kullanım değişikliğinin tahmini için kullanılabilir (Hu \& Lo, 2007).

\section{Markov Zincir Modeli}

Bir durumdan bașka bir duruma değișimin tahmin edilmesi için kullanılan Markov Zincir modeli, Markov stokastik süreç sistemlerinin formasyonuna dayanmaktadır (Muller \& Middleton, 1994). Markov Zincir modeli, arazi kullanımı/arazi örtüsü değişikliklerini, boyutlarını ve eğilimlerini modellemek ve simüle etmek için yaygın olarak kullanılmaktadır (Muller \& Middleton, 1994), (López, Bocco, Mendoza, \& Duhau, 2001). Markov Zincir modeli, belirli bir zaman dilimi içerisinde, arazi kullanımındaki değișikliği bir durumdan farklı bir duruma geçiş alanlarına göre analiz etmekte ve özetlemektedir (Coppedge, Engle, \& Fuhlendorf, 2007). Ayrıca, üretilen olasılık geçiş alanları, gelecekteki arazi kullanım değișikliği ve kentsel yayılma modellerinin olası senaryolarının tahmin edilmesi amacıyla da kullanılabilir (Dadhich \& Hanaoka, 2011). Öte yandan, Markov Zincir modeli, mekansal dağılımdaki değişiklikleri modelleme ve simüle etme hususunda işlevsizdir. Ancak, arazi kullanım değişikliklerinin miktarının tahmin edilmesi ve hesaplanması noktasında oldukça etkili ve güçlü bir modeldir (Yang et al., 2012). Gelecekteki arazi kullanım değişikliklerinin tahmin edilmesinde koşullu olasılık formülünden yararlanılmaktadır ve Denklem 1 ve Denklem 2 ile gösterilmektedir:

$$
\begin{gathered}
S(t+1)=P_{i j} \times \mathrm{S}(\mathrm{t}) \\
\left\|P_{i j}\right\|=\left\|\begin{array}{lll}
P_{11} & P_{12} & P_{1 n} \\
P_{21} & P_{22} & P_{2 n} \\
P_{n 1} & P_{n 2} & P_{n n}
\end{array}\right\| \\
0 \leq P_{i j}<1 \quad \text { ve } \quad \sum_{1}^{n} P_{i j}=1
\end{gathered}
$$

$$
(i, j=1,2, \ldots n)
$$

Denklem 1'de $S(t)$, sistemin $t$ zamanındaki durumudur, $S(t+1)$, sistemin $(t+1)$ zamanındaki durumudur. $P_{i j}$ ise bir durumdaki geçiş olasılığı matrisini ifade etmektedir.

Arazi kullanımı ve arazi örtü değişikliği zaman içinde ekonomik, sosyal ve biyofiziksel faktörlerin dinamiklerini ve etkileşimini yansıtmaktadır. $\mathrm{Bu}$ nedenle, arazi kullanımı/arazi örtüsü verilerinde durağanlık beklemek rasyonel değildir. Bununla birlikte, şayet zaman aralığı çok büyük değilse, arazi kullanımı/arazi örtüsü değişikliği durağan olarak kabul edilebilir. Arazi kullanımı ve arazi örtüsü değişiklikleri gibi dinamik sistemleri simüle etmek için uzaktan algılama amaçlı uydu sistemleri ve CBS ile entegre Markov Zincir modelinin uygulanması oldukça büyük bir gelişmiş analiz imkânı sağlamaktadır.

\section{Hücresel Otomata Markov Zincir Modeli}

Tüm simülasyon teknikleri arasında, Hücresel Otomata modeli en çok uygulanan yöntemlerden birisidir ve 1990'lardan beri arazi kullanımını modellemek için kullanılmaktadır (H. Wu et al., 2019; Xu et al., 2019). Hücresel Otomata, birbirine bağlı yerel değişkenlerin ilişkilerinin küresel değişiklikler sergilediği bir hücre ızgarasıyla temsil edilen ayrık dinamik sistemler olarak tanımlanır. Hücresel Otomata uygulamaları, kentsel yayılma modelleme çalışmalarında yaygın olarak kullanılmaktadır (Sudhira, Ramachandra, \& Jagadish, 2004). Özellikle, kentsel alanlar gittikçe genişledikçe ve mekansal veriler deneysel araştırmalar için daha da kullanılabilir hale geldikçe artan bir önem kazanmışlardır. Kentsel yayılma için hücresel otomatlar genellikle montaj, test etme, doğrulama ve kalibrasyonla ilgili benzer çerçeveleri korurken, kullanılan modelleme teknikleriyle ilgili bazı kavramsal sorunlar ortaya çıkmaktadır. Şekil.1'de gösterildiği gibi, birçok çalışmada Hücresel Otomata ile kentsel yayılma tahmin modellerine çeşitli algoritmalar dahil edilmiştir. Daha sonra bu teorik yaklaşımlar gerçek dünya uygulamalarında kullanılmıștır. Çok sayıda uygulamada, gerçek veriler (Triantakonstantis \& Mountrakis, 2012) kullanılarak kentsel yayılma tahmin modelleri geliştirmek için Hücresel Otomata yöntemi dahil edilmiştir.

Arazi kullanım değișikliği modelleme yöntemlerinin güvenilirliğinin geliștirilmesi için iki ya da daha fazla simülasyon tekniği birleştirilerek her bir modelin sağladığı avantajlardan yararlanmak mümkündür (X. Liu, Li, Yeh, He, \& Tao, 2007), (Yang et al., 2012). CA-MC, yakın zamanda belirgin mekansal parametrenin simülasyonunda ve gelecekteki arazi kullanım değişikliklerinin tahmininde kullanılmıştır (Wang, Zheng, \& Zang, 2012). Entegre CA-MC modeli, arazi kullanım değişim miktarının tahmini için Markov Zincir modeli'nin avantajlarını ve belirgin mekânsal parametrenin simülasyonu için Hücresel Otomata Modeli'nin avantajlarını bir araya getirmektedir. (Yang et al., 2012). Sonuç olarak CA-MC modeli ile uzaktan algılama verilerinden türetilen CBS ve arazi kullanımı/arazi örtüsü değișikliği haritalarının birlikte 
kullanılması mekansal ve zamansal arazi kullanım değişikliklerinin etkili bir şekilde modellenmesine ve simüle edilmesine imkân tanımaktadır (Myint \& Wang, 2006), (Kamusoko, Aniya, Adi, \& Manjoro, 2009), (Guan et al., 2011). Ayrıca, CA-MC modeli tarafından sağlanan arazi kullanımı değişikliği simülasyon sonuçları oldukça güvenilirdir ve bu modelin kullanımı sosyo-ekonomik, istatistiksel ve tarihsel verilerin eksikliğinin giderilmesinde de yararlıdır (Fan, Wang, \& Wang, 2008), (Zhang, Ban, Liu, \& Hu, 2011). CA-MC modelleme işleminde, arazi kullanım sınıflarının zamansal değișiklikleri Markov Zincir yaklaşımıyla üretilen geçiş matrislerine dayalı olarak yönetilmekteyken (López et al., 2001) mekânsal değişiklikler ise geçiş potansiyel haritaları, mahalle konfigürasyonu ve Hücresel Otomata model süreci sırasında yerel geçiş kuralı ile kontrol edilmektedir (White \& Engelen, 1993), (F. Wu, 2002), (Li \& Gar-On Yeh, 2004). Bununla birlikte, arazi kullanım değişikliklerini ve arazi kullanımındaki değişikliklere neden olan belirgin parametrelerin daha iyi anlaşılması için biyofiziksel ve sosyoekonomik verilerin CA-MC modeline dahil edilmesi gerekli görülmektedir.

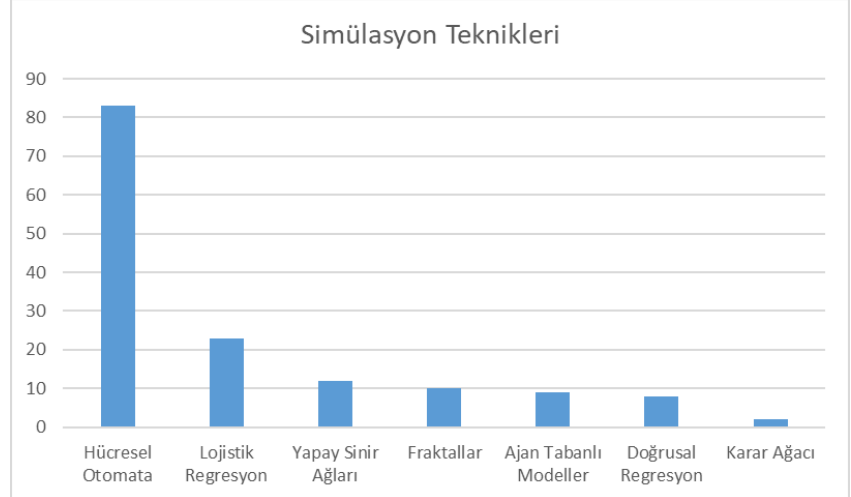

Şekil 1. Popülariteye göre sıralanan temel kentsel yayılma tahmin algoritmaları (\%) (Triantakonstantis \& Mountrakis, 2012)

\section{6. ÇALIŞMA ALANI}

Kerkük ili, Irak'ın kuzey bölgesinin merkezinde ve coğrafi olarak, $34^{0} 42^{\prime}-35^{0} 50^{\prime} \mathrm{K}$ ve $43^{0} 17^{\prime}-44^{0} 44^{\prime} \mathrm{B}$ boylamları arasında yer almaktadır. Kerkük ili, kuzeyinde Erbil, güneyinde ve batısında Salahaddin, doğusunda ise Süleymaniye illeri ile çevrilidir (Şekil 2). Kerkük ili dört ilçeden oluşmaktadır. Birincisi, nüfusun çoğunluğunun yaşadı̆̆ı ve ilin yönetim merkezi olan Kerkük. İkincisi merkeze yaklaşık 40 kilometre uzaklıkta ve ilin güneyinde bulunan Dakuk ilçesidir. Üçüncüsü, ilin doğusunda yer alan ve nispeten küçük bir yerleşim birimi olan Dibis ve dördüncüsü ise ilin güney ve güneybatısında bulunan Havija ilçesidir. Dört ilçenin kapladığı toplam alan yaklaşık 9680 km²'dir. Kerkük ili, son yirmi yıldır, bu çalıșmada analiz edilen ve araștırılan arazi kullanımı ve arazi örtüsünde büyük değișikliklerin meydana gelmesine yol açan hızlı bir kentleșmeye tanık olmuştur.

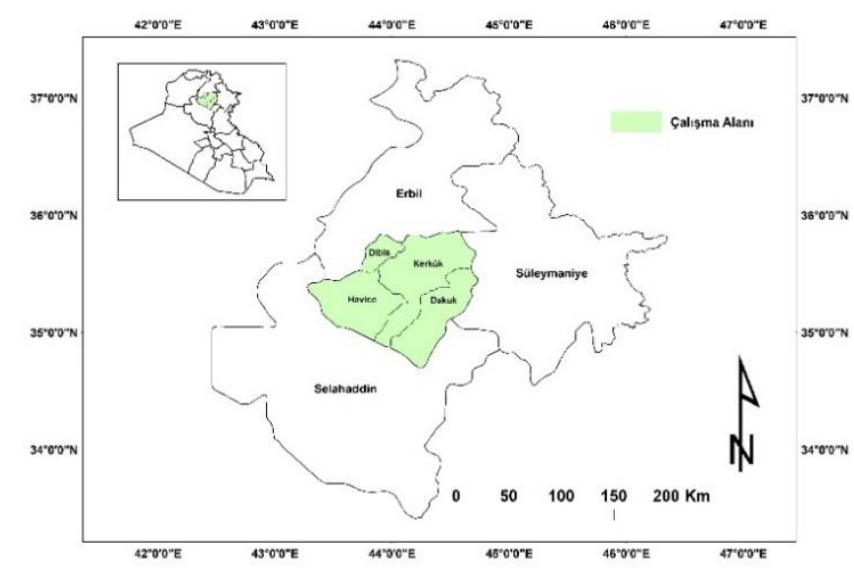

Şekil 2. Çalışma alanı

\section{MATERYAL ve METOT}

Bu çalışmada görüntü ön işlemleri için ENVI yazılımı, görüntü sınıflandırma ve değişiklik tespiti süreçleri için ArcGIS 10.4.1 ve gelecekteki arazi kullanım tahmini için TerrSet yazılımındaki Land Change Modeler (LCM) aracı kullanılmıştır. LCM, değişim analizi, geçiş potansiyeli modellemesi ve ardından değişiklik tahmini adımlarını gerçekleştiren entegre bir yazılım modülüdür. Gelecekteki senaryoları modellemek için zaman 1'den zaman 2'ye kadar arazi örtüsü haritalarının tarihsel değişimini izlemektedir. CA-MC modeli, Markov Zincir matrislerine ve geçiş duyarlılık haritalarına dayanarak LCM aracı ile gerçekleştirilmiștir. $\mathrm{Bu}$ çalışmada, kullanılan veri kümeleri Birleşik Devletler Jeoloji Kurumu'nun (United States Geological Survey-USGS) sağladığı uydu görüntüleridir.

2002, 2010, 2014 ve 2018 yılları için arazi kullanımı ve arazi örtüsü haritasının üretilmesinde, Landsat- 8 ve Landsat TM (4 Ağustos 2002, 14 Ocak, 2010, 22 Eylül 2014 ve 17 Eylül 2018) verilerinden yararlanılmıştır. Farklı yılların aynı aylarına ait uydu görüntülerine istenmeyen yüksek bulutluluk oranı ve uydu geçişlerinin gece saatlerine denk gelmesinden dolayı erişilememiştir. Kullanılan uydu görüntüleri $30 \mathrm{~m}$ (pankromatik bantlar için $15 \mathrm{~m}$ ) zemin çözünürlüğüne ve 7 spektral banda sahiptir (11 spektral banda sahip olan Landsat-8 görüntüleri hariç). Arazi kullanımı/arazi örtüsü sınıflandırmasında Anderson șemasının değiștirilmiș bir versiyonu uygulanmıştır (Anderson, 1976). Kategoriler; (1) kentsel alan veya yerleşim alanı, (2) tarım alanı (3) su (4) açık alan olarak belirlenmiştir.

Kullanılan her bir Landsat görüntüsünün iyileştirilmesi için histogram eşitleme yönteminden yararlanılmıştır. Tek bir yüksek çözünürlüklü görüntü elde etmek üzere, Landsat-8'den elde edilen (2014 ve 2018) görüntüler Gram-Scmidt işleme yöntemi kullanılarak, yüksek çözünürlüklü pankromatik bant 8 ve daha düşük çözünürlüklü bantları birleștirilmiştir.

$\mathrm{Bu}$ çalışma, yüzey yansıtıcılarındaki ince değişikliklerin saptanmasını gerektirdiğinden dolayı radyometrik düzeltmeden yararlanılmıştır. Radyometrik düzeltme, hataları azaltmanın veya düzeltmenin yanında uzaktan algılanan verilerinin yorumlanabilirliğinin ve kalitesinin artırılması amacıyla uygulanmıştır. Bu 
görüntü normalleştirme yöntemi, uzaktan algılama yöntemi ile elde edilen görüntüler üzerindeki, güneş açısındaki değișimler, atmosferik nem ve toprak nemi gibi etkilerden oluşan değişimleri en aza indirebilmekte ya da tamamen ortadan kaldırabilmektedir (Jensen, 1996). Landsat görüntülerinin sınıflandırılması için denetimli bir imza çıkarımı kullanılmıştır (Şekil 3). Özellik seçiminin hem istatistiksel hem de grafiksel analizleri yapılmıştır. Buna göre; sınıfları ayırmada en etkili bantların, yeşil (bant 2), kırmızı (bant 3) ve yakın kızılötesi (bant 5) bantlar olduğu görülmüş ve sınıflandırma işlemlerinde bu bantlar kullanılmıştır. Eğitim seti verileri, ekran üzerinde çokgen seçilmesi yöntemi kullanılarak toplanmıştır. Her arazi kullanımı kategorisini oluşturan tüm spektral sınıfların eğitim istatistiklerinde yeterince temsil edilmesini sağlamak için her görüntü için çeşitli eğitim veri kümeleri seçilmiştir.

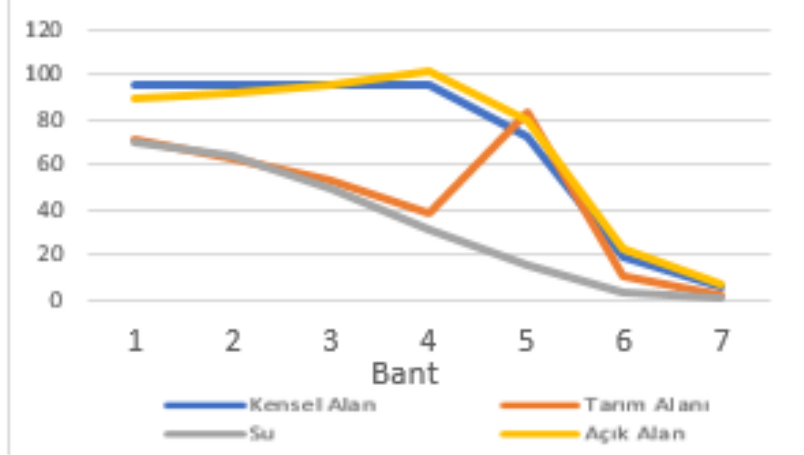

Şekil 3. Sınıfların spektral imzası

Kullanılan paket program içinde bulunan (i) en kısa mesafe, (ii) Mahalanobis mesafesi ve (iii) maksimum olabilirlik sınıflandırma yöntemi teknikleri ile denetimli sınıflandırma yapılmıştır. Bu yöntemler arasında en iyi sonucu veren maksimum olabilirlik sinıflandirma tekniğine ait sonuçlar sunulmuştur. Şekil 4'te arazi kullanım haritalarının elde edilmesine yönelik metodoloji görselleștirilmiștir. Maksimum olabilirlik sinıflandırma metodu, kesin örnekler kullanılması halinde basit ve güçlü bir yaklaşım olarak kabul edilmektedir. Sınıflandırılmış tüm haritaların doğruluğu, her bir arazi kullanımı ve arazi örtüsü kategorisi için 50 adet örneğin seçildiği, katmanlı rastgele örnekleme yöntemi ile kontrol edilmiştir. Arazi kullanımı ve arazi örtüsü değişiklik tespitinde çapraz tablolama tespit yöntemi kullanılmış ve bir değișim matrisi üretilmiștir. Toplam arazi kullanımı ve arazi örtüsü değişikliklerinin alansal verileri ile 2002-2018 yılları arasını kapsayan dönemde her bir kategorideki kazanç ve kayıplar belirlenebilmekte ve derlenebilmektedir. Değişim matrisi, çalışma alanındaki temel değişiklik türleri hakkında bilgi vermektedir. Arazi kullanımı ve arazi örtüsü değişikliklerinin doğasını, oranını ve yerini analiz etmek için her bir kategori için bir dizi kazanç ve kayıp görüntü seti üretilmiştir.

CA-MC modeli, Şekil 4'te verilen diyagramda gösterildiği gibi gelecekteki arazi kullanım değişikliklerini simüle etmek ve tahmin etmek için uygulanmıştır. Arazi kullanım geçiş olasılık matrisi ve geçiş kuralları CA-MC modellemesi yapmak için Markov Zincir analizi kullanılarak belirlenmiştir. Önceki arazi kullanım durumuna bağlı olarak, gelecekteki arazi kullanım değişiklikleri modellenmiştir, yani 2002-2010 ve 2010-2014 yıllarında arazi kullanım haritaları arasındaki geçiş olasılıkları sırasıyla 2014 ve 2018 yıllarındaki değişiklikleri tahmin etmek, yani modeli kalibre etmek ve doğrulamak için kullanılmıştır. Buna karşılık gelecekteki değişiklikleri tahmin etmek için 2014 ve 2018 arazi kullanım haritalarından yararlanılmıştır. Buna ek olarak, geçiş olasılığı matrisleri dönüşüm kurallarını sağlamakta ve farklı arazi kullanım sınıflarının diğer sınıflara değişim olasılığını göstermekteyken, geçiş alanı matrisleri gelecekteki tahminlerde diğer arazi kullanım sınıflarındaki arazi kullanım değișikliği miktarını yansıtmaktadır. $\mathrm{Bu}$ çalışmada, kalibrasyon ve doğrulama süreçlerinin yürütülmesinde 2010 ve 2014 yılları temel alınmış, 2030 ve 2035 yıllarındaki arazi kullanım değişikliğinin tahmin edilmesi için ise 2018 yılı başlangıç noktası olarak kabul edilmiştir.

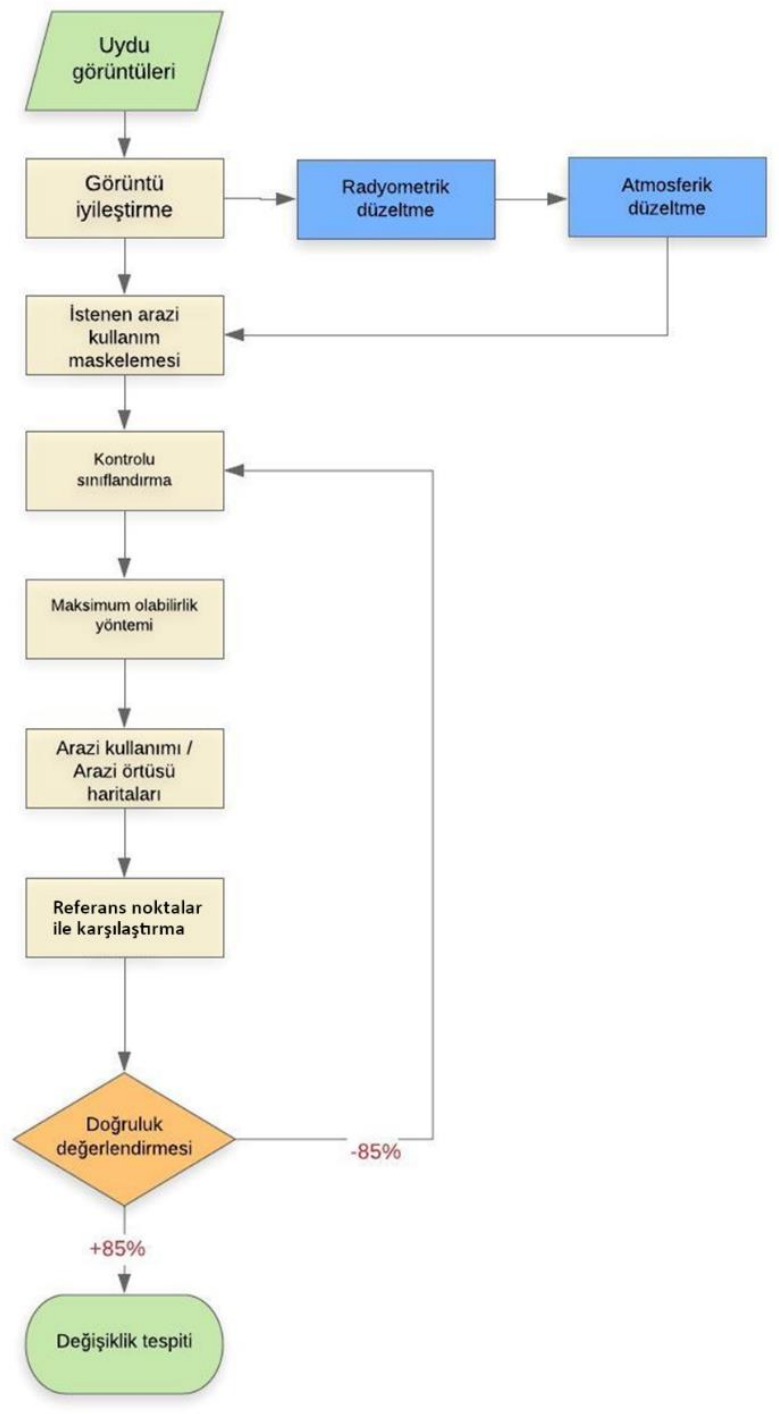

Şekil 4. Arazi kullanımı değişiklik tespiti akış diyagramı 

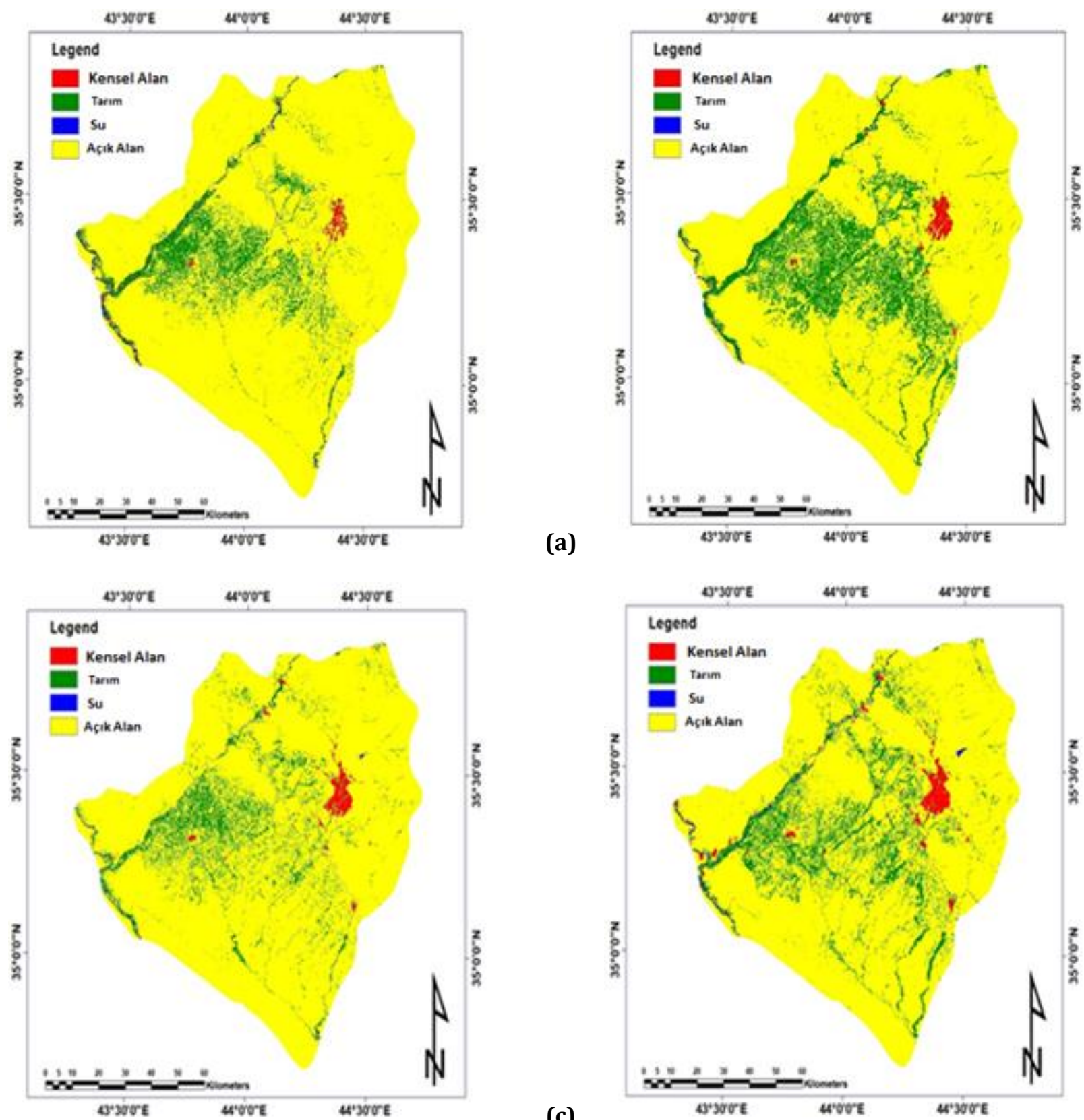

(c)

Şekil 5. Kerkük șehri arazı kullanım haritaları: (a) 2002 yılı, (b) 2010 yılı, (c) 2014 yılı ve (d) 2018 yılı.

\section{BULGULAR ve TARTIŞMA}

\subsection{Arazi Kullanımı/Arazi Örtüsü Değişiklik Tespiti}

2002, 2010, 2014 ve 2018 yllarına ait arazi kullanımı ve arazi örtüsü haritaları Landsat görüntülerinden üretilmiș ve sirasiyla Şekil 5 'te gösterilmiştir. 2002, 2010 ve 2018 yıllarında arazi kullanım/arazi örtüsü haritalarının toplam doğruluğu sirasıyla \%95.58, \%94.93, \%93.53 ve \%93.57 olarak belirlenmiștir. 2002, 2010 ve 2018 haritaları için Kappa standart katsayıları sirasıly $0,94,0,93,0,91$ ve 0,93 olarak tespit edilmiştir. Bu bağlamda, verilerin USGS sınıflandırma șemasında öngörülen standartların minimum \%85'ini karşıladığını söylemek mümkündür (Anderson, 1976). Bu nedenle doğruluk oranı, arazi kullanımı ve arazi örtüsü değişikliklerinin değerlendirilmesi için yeterlidir. Tablo 1'de 2002'den 2018'e kadar arazi kullanımı ve arazi örtüsü değişim matrisi gösterilmektedir. Tablodan açıkça anlaşılacağı üzere 16 yllık sürede önemli bir değiş̧ikliğin gerçekleștiğini söylemek mümkündür. Kentsel veya yerleşim alanları 2002 yılında 7421 hektar iken 2018 yılında 17091 hektara çıkmış, 18 yll içinde \%130 oranında artmıștır. Aynı dönemde tarım arazileri de 986.33 hektardan 1208.86 hektara çıkmıştır. Ancak bu artış gerçek bir değişiklik olmayabilir, daha ziyade piksellerin yanlış sınıflandırılması sebebiyle olabilir. Örneğin, 79 hektar kentsel alanın su alanlarından geldiği görülmektedir ancak bu durumun gerçek olmadığı söylemek mümkündür. Çünkü, bölge hakkındaki bilgilere göre, o dönemde su alanlarından yerleşim alanlarına bir dönüşüm olmamıștır. Ancak, 79 hektarın toplam kentsel alanlarının sadece \%1,30'lük bir kısmını olușturması nedeniyle bu durum ihmal edilebilir. Hataların oranı \%15'i aşmadığı için USGS sınıflandırma şemasına göre kabul edilebilir bir oran olarak ele alınabilir.

Tablo aynı zamanda su alanında aynı dönemde 6008 hektardan 6518 hektara kadar bir artıș olduğunu göstermektedir. Bu artış, Kerkük şehrinde üç adet baraj 
inşa edilmesinin bir sonucu olarak ortaya çlkmaktadır. Bunlar, şehrin kuzeyindeki Laylan bölgesinde yer alan Şirin barajı ve Balkana barajı (bu iki baraj 2009 yılında açılmıştır), diğeri ise 2016 yılında açllan Kerkük'ün kuzeybatısındaki Şwan bölgesinde yer alan Şiwa Sur Barajı'dır. Buna karşılık, açık alanlar 889.416 hektar iken 85.684 hektar olacak şekilde bir azalma göstermiştir.

Şekil 6 (a)'da verilen 2002-2018 yılları arası değişim haritası, kentsel yayılmanın ilin tüm bölgelerinde meydana geldiğini göstermektedir. Ancak bölgeler arasında oransal farklılıklar vardır. Yayılma, şehir sınırlarında yer alan bölgelerde daha çok hissedilmektedir, șehir merkezindeki alanlarda ise dikey gelişmenin gerçekleştiği görülmektedir. Son birkaç yıl öncesini kapsayan süreçte boş olan arazilerin binalarla dolduğu görülmektedir. $\mathrm{Bu}$ kentsel yayılma hızının gelecekte artması beklenmektedir. Şekil 6 (b) ve Şekil 6 (c)'de verilen tahmin haritaları, kentsel alanların 2030 ve 2035 'te sırasıyla 26981.9 ve 35927.9 hektarı aşacağını ve şehirlerin eteklerinde yeni kentsel grupların ortaya çıkacağını göstermektedir. CA-MC modeline ait akış diyagramı Şekil 7'de verilmiştir.

Tablo 1. Arazi kullanımı/arazi örtüsü değişim matrisi (ha). 2002

\begin{tabular}{|l|c|c|c|c|c|c|}
\cline { 2 - 8 } \multicolumn{1}{c|}{} & $\begin{array}{c}\text { Kentsel } \\
\text { Alan }\end{array}$ & Tarım & Su & $\begin{array}{c}\text { Açı } \\
\text { Alan }\end{array}$ & $\begin{array}{c}\text { Toplam } \\
\text { Satır }\end{array}$ & Sınıf Toplamı \\
\hline Kentsel Alan & 4897 & 598 & 79 & 11517 & 17091 & 17108 \\
\hline Tarım & 888 & 44265 & 1764 & 73970 & 120886 & 121010 \\
\hline Su & 198 & 769 & 3216 & 2336 & 6518 & 6539 \\
\hline \multirow{2}{*}{} & 1437 & 53001 & 948 & 801468 & 856854 & 859718 \\
\hline
\end{tabular}

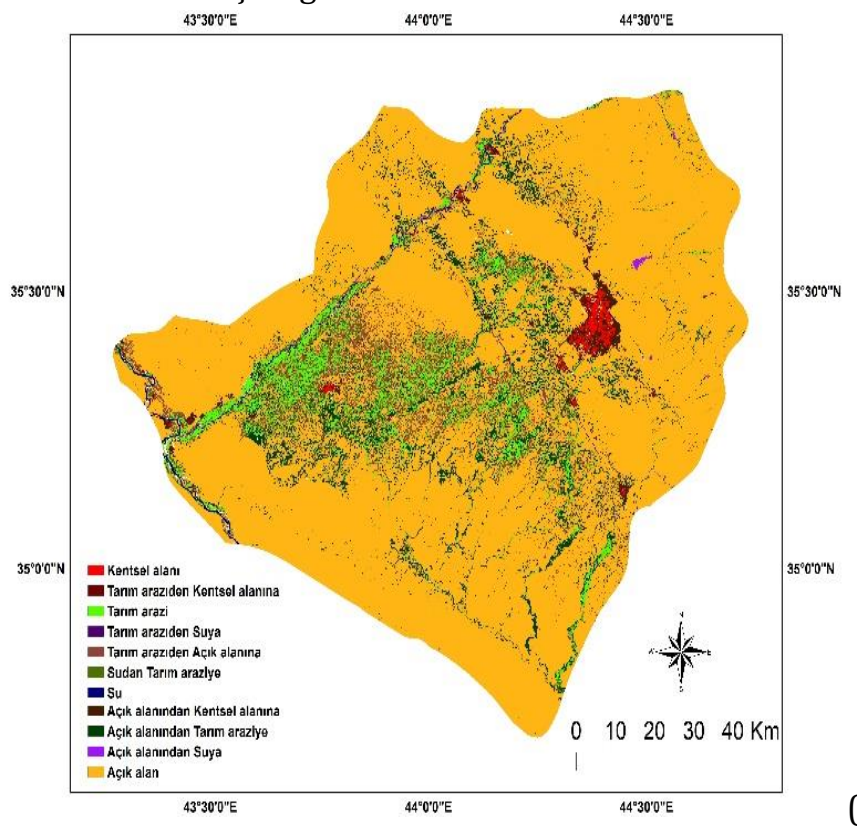

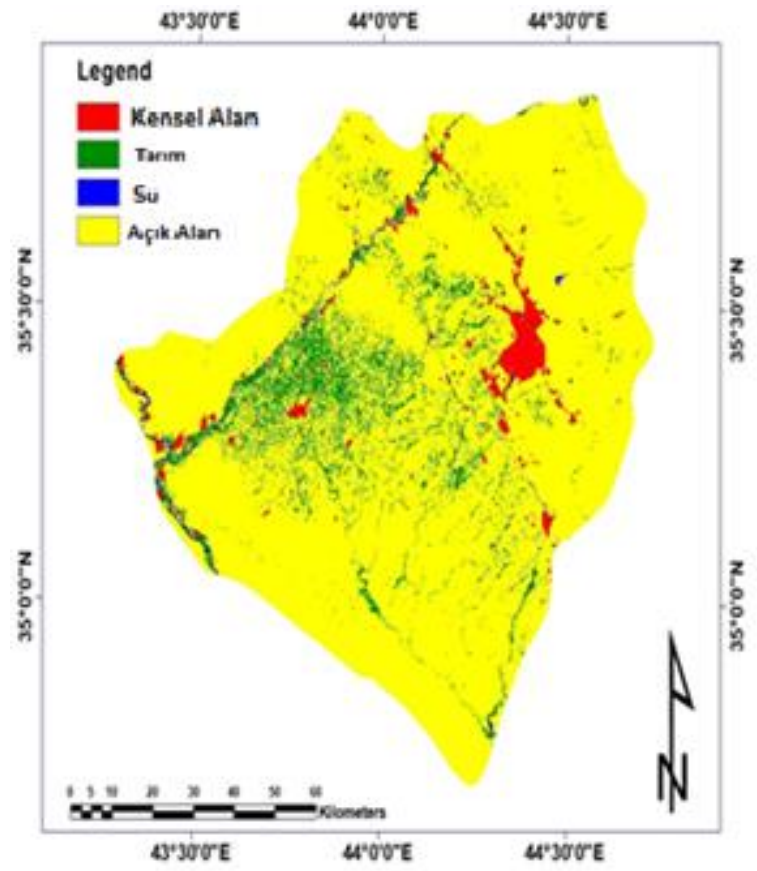

(a) 


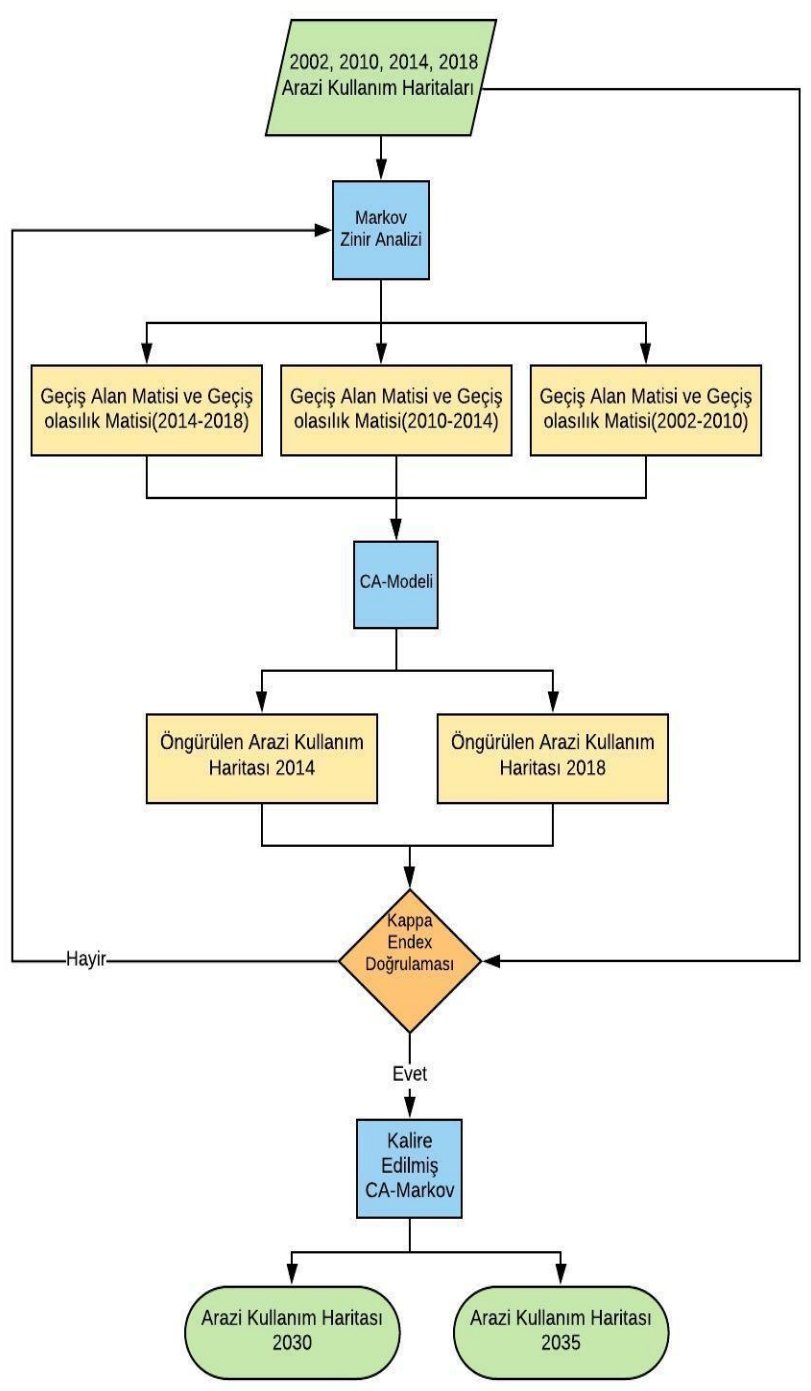

Şekil 7. CA-MC Modeli akış diyagramı

\subsection{Arazi Kullanım/Arazi Örtüsü Değişiklik Sürecinin Tutarlılığı}

Geçiş olasılık matrisleri, Tablo 2'de gösterildiği gibi Markov Zincir modeli kullanılarak hesaplanmıştır. Bu geçiş olasıllk matrisleri, 2002-2010, 2010-2014 ve 20142018 dönemlerinde muhtemel arazi kullanım oranlarını vermektedir. Tablo 2'den, kentsel alanların geçiş olasılıklarının istikrarsız olduğunu ve 2002-2010 döneminde 0,526 iken, 2014-2018 döneminde 0,7687 değerine çok hızlı ulaştı̆̆ını görmek mümkündür. Ayrıca, 2002-2010 yılları arasında çorak topraklardan kentsel alanlara yayılan geçiş olasılıklarının 0,2368 olduğunu ve 2010-2014 döneminde 0,2496'a yükseldiğini, 20142018 döneminde ise $0,197 ' \mathrm{e}$ düştüğünü görmek mümkündür. Geçiş matrislerinin istikrarsızlığı, gelecekte arazi kullanımın kesin olarak tahmin edilmesinde zorluklar yaratabilir. Diğer bir zorluk, arazi kullanım sürecinin, modelin tahmin edemediği ekonomik ve politik faktörler gibi dış faktörlere bağlı olmasıdır. Ancak bu çalıșmada, arazi kullanımını geçiș olasılıklarının istikrarlı olmaya devam edeceği kabul edilmiş ve gelecek yıllara ait tahmin bu varsayıma dayanarak yapılmıştır.
Tablo 2. 2002-2010, 2010-2014 ve 2014-2018 dönemlerine ait geçiş olasılık matrisleri

\begin{tabular}{|c|c|c|c|c|c|}
\hline & & $\begin{array}{c}\text { Kentsel } \\
\text { Alan }\end{array}$ & Tarım & $\mathrm{Su}$ & Açık Alan \\
\hline & Kentsel Alan & 0.5263 & 0.2141 & 0.0229 & 0.2368 \\
\hline \multirow[t]{4}{*}{$2002-2010$} & Tarım & 0.0018 & 0.5643 & 0.0044 & 0.4295 \\
\hline & $\mathrm{Su}$ & 0.0113 & 0.4388 & 0.4221 & 0.1279 \\
\hline & Açık Alan & 0.0104 & 0.2341 & 0.0035 & 0.7521 \\
\hline & Kentsel Alan & 0.7278 & 0.0225 & 0.0002 & 0.2496 \\
\hline \multirow[t]{4}{*}{$2010-2014$} & Tarım & 0.0009 & 0.3079 & 0.0041 & 0.6872 \\
\hline & $\mathrm{Su}$ & 0.017 & 0.1586 & 0.4181 & 0.4063 \\
\hline & Açık Alan & 0.0193 & 0.1632 & 0.0026 & 0.8149 \\
\hline & Kentsel Alan & 0.8071 & 0.0362 & 0.0253 & 0.1314 \\
\hline \multirow[t]{3}{*}{ 2014-2018 } & Tarım & 0.0027 & 0.4672 & 0.008 & 0.5221 \\
\hline & $\mathrm{Su}$ & 0.0231 & 0.1945 & 0.5243 & 0.258 \\
\hline & Açılk Alan & 0.0219 & 0.2017 & 0.0049 & 0.7716 \\
\hline
\end{tabular}

\subsection{Model Doğrulaması ve Gelecekteki Arazi Kullanım Değişikliği Tahmini}

CA-MC modelinin arazi kullanım durumu tahmininde kullanılması ilk kez 2014 yılına rastlamaktadır. Daha sonra, model güvenilirliğinin sağlanması için 2018 yılında arazi kullanım değişikliğinin tahmini amacıyla tekrar kullanılmıştır. Model doğrulaması için 2014 ve 2018 yllarında öngörülen arazi kullanım haritası miktar ve konum açısından geçerliliğinin kontrol edilmesi için Kappa katsayısı değerlerinin kullanıldığı referans değerler ile karşılaștırılmıştır (Zhang et al., 2011), (Kamusoko et al., 2009). Referans değerler göz ile seçilerek sınıflandırılmıştır. Tablo 3, referans ve karşılaştırma haritaları arasındaki miktar ve konum uyuşma veya uyuşmazlıklarını göstermektedir.

Doğrulama için haritaları karşılaştırırken, nicelik hatası ile konum hatasını ayırt edilebilir. Bir haritadaki bir sınıfa ait hücre miktarı diğer haritadaki o sınıfa ait hücrelerin miktarından farklı olduğunda nicelik hatası oluşur. Nicelik hatasının mevcut olmadığı durumlarda, bir sınıfa ait bir hücrenin bir haritadaki konumunun, o hücrenin diğer haritadaki konumundan farklı olduğu durumlarda konum hatası meydana gelebilir.

Tablo 3'te verilen Kappa istatistikleri ve bileşenlerine ait tanımlama ve açıklamalar, sırasıyla, Tablo 4 ve Tablo 5 ' te verilmiştir.

Nicelikle ilgili üç olası bilgi seviyesinden bahsetmek mümkündür. Bunlardan $n$ bilgi olmadığı, $m$ orta düzeyde bilginin var olduğu ve $p$ ise eksiksiz bilgiye sahip olduğu anlamina gelmektedir.

Referans harita ile karşılaştırma haritası arasındaki uyuşmayı temsil eden $M(m)$ değeri 0,9323 olarak tespit edilmiștir ki bu değer eksiksiz durum değeri olan 0,9260 değerinden yüksektir. Bu indeks, haritalar arasında en çok kullanılan uyuşum ölçüsüdür. Ancak, yorumlanma hususunda bir takım zorluklar söz konusu olabilmektedir. Öyle ki, yeryüzü şekilllerinin bir kısmı şans eseri ve tesadüfen doğru olabilir. Ancak, şans eseri ortaya çıkan uyuşum ihtimalinin değeri 0.2000 olup, bu oldukça küçük bir değerdir. Nicelik olarak uyuşmama miktarı ve hücre seviyesindeki uyușmama değerleri sırasıyla 0,0212 ve 0.0463 olarak tespit edilmiştir ve bu 
değerlerin nispeten düşük olduğunu belirtmek mümkündür. Tabloda gösterildiği gibi, referans ve karşılaş̧ırma haritaları arasındaki uyuşma olan Cohen'in önerdiğini geleneksel Kstandard değeri 0,8799'dir. Her bir hücrenin yeryüzü șekilleri ile ne derecede iyi örtüştüğünü gösteren Klocation değeri 0,9143 olarak tespit edilmiştir. Hücrelerin katmanlar içinde ne derece iyi konumlandığını gösteren Klocation strata değeri de 0,9143 olarak tespit edilmiştir ki bu hayli yüksek bir örtüșmeyi göstermektedir. Bu doğrulama sonuçları, referans haritalar ile karşılaştırma haritaları arasında oldukça iyi bir tutarlılığın söz konusu olduğunu göstermektedir. Doğrulama adımının bir sonucu olarak, model için en uygun geçiş kuralları hesaplanabilir ve daha sonra gelecekte arazi kullanımının öngörülmesinde kullanılabilir. 2018'deki arazi kullanımının başarılı bir şekilde gerçekleştirilen modellemesine dayanarak elde edilen 2030 ve 2035 yılları için arazi kullanım değerleri Şekil 8'de verilmiştir.

Tablo 3. Referans ve karşıllaştırma haritaları arasındaki uyuşma/uyuşmazlık

\begin{tabular}{llll} 
& \multicolumn{3}{c}{ Nicelik Bilgileri } \\
\hline & $\mathrm{P}(\mathrm{n})=0,4825$ & $\mathrm{P}(\mathrm{m})=0,9788$ & $\mathrm{P}(\mathrm{p})=1,000$ \\
\hline $\mathrm{K}(\mathrm{n})=0,4825$ & $\mathrm{~K}(\mathrm{~m})=0,9788$ & $\mathrm{~K}(\mathrm{p})=1,000$ \\
\cline { 2 - 4 } & $\mathrm{M}(\mathrm{n})=0,4552$ & $\mathrm{M}(\mathrm{m})=0,9323$ & $\mathrm{M}(\mathrm{p})=0,9260$ \\
\hline $\mathrm{H}(\mathrm{n})=0,2000$ & $\mathrm{H}(\mathrm{m})=0,4360$ & $\mathrm{H}(\mathrm{p})=0,4276$ \\
\hline $\mathrm{N}(\mathrm{n})=0,2000$ & $\mathrm{~N}(\mathrm{~m})=0,4360$ & $\mathrm{~N}(\mathrm{p})=0,4276$
\end{tabular}

$\begin{array}{ll}\text { Şans Uyuşması } & 0,2000 \\ \text { Nicelik Uyuşması } & 0,2360 \\ \text { Katman Uyuşması } & 0,0000 \\ \text { Hücre Uyuşması } & 0,4963 \\ \text { Hücre Uyuşmama } & 0,0465 \\ \text { Katman Uyuşmama } & 0,0000 \\ \text { Nicelik Uyuşmama } & 0,0212 \\ \text { Kno (nicelik) } & 0,9154 \\ \text { Klocation (konum) } & 0,9143 \\ \text { Klocation Strata (konum katman) } & 0,9143 \\ \text { Kstandard (standart) } & 0,8799\end{array}$

Tablo 4. Kappa istatistikleri ve tanımları(Pontius Jr, 2002)

\begin{tabular}{|c|c|c|}
\hline $\begin{array}{l}\text { İstatistik } \\
\text { Adı }\end{array}$ & Açıklama & Tanımı \\
\hline Kno & $\begin{array}{l}\text { Doğru olarak } \\
\text { sınıflandırılmış } \\
\text { piksellerin tahmin edilen } \\
\text { piksellere oranıdır }\end{array}$ & $\begin{array}{l}\{M(m)- \\
N(n) /\{P(p)- \\
N(n)\}\end{array}$ \\
\hline Klocation & $\begin{array}{l}\text { Konum bazında anlaşma } \\
\text { düzeyiyle ilişkili uzamsal } \\
\text { düzeydeki doğruluğu } \\
\text { temsil eder }\end{array}$ & $\begin{array}{l}\{\mathrm{M}(\mathrm{m})- \\
\mathrm{N}(\mathrm{m})\} /\{\mathrm{P}(\mathrm{m})- \\
\mathrm{N}(\mathrm{m})\}\end{array}$ \\
\hline $\begin{array}{l}\text { Klocation } \\
\text { strata }\end{array}$ & $\begin{array}{l}\text { Ön tanımlı bir katmana } \\
\text { doğru atanma ile ilgilidir }\end{array}$ & $\begin{array}{l}\{\mathrm{M}(\mathrm{m})- \\
\mathrm{H}(\mathrm{m})\} /\{\mathrm{K}(\mathrm{m})- \\
\mathrm{H}(\mathrm{m})\}\end{array}$ \\
\hline Kstandard & $\begin{array}{l}\text { Cohen'in önerdiği } \\
\text { kstandard katsayısı } \\
\text { doğru atanmış } \\
\text { piksellerin şans eseri } \\
\text { doğru atanmış piksellere } \\
\text { oranıdır. }\end{array}$ & $\begin{array}{l}\{\mathrm{M}(\mathrm{m})- \\
\mathrm{N}(\mathrm{m})\} /\{\mathrm{P}(\mathrm{p})- \\
\mathrm{N}(\mathrm{m})\}\end{array}$ \\
\hline
\end{tabular}

Tablo 5. Kappa bileşenleri ve tanımları (Pontius Jr, 2002).

\begin{tabular}{ll}
\hline Bileşen Adı & Tanımı \\
\hline Nicelik Uyuşmama & $\mathrm{P}(\mathrm{p})-\mathrm{P}(\mathrm{m})$ \\
\hline Katman Uyuşmama & $\mathrm{P}(\mathrm{m})-\mathrm{K}(\mathrm{m})$ \\
\hline Hücre Uyuşmama & $\mathrm{K}(\mathrm{m})-\mathrm{M}(\mathrm{m})$ \\
\hline Hücre Uyuşması & MAX [M(m)-H(m), 0] \\
\hline Katman Uyuşması & MAX [H(m)-N(m), 0] \\
\hline Nicelik Uyuşması & Eğer MIN [N(n), N(m), H(m), \\
& M(m)]=N(n), \\
& $\begin{array}{l}\text { ise MIN [N(m)-N(n), H(m)- } \\
\text { N(n), M(m)-N(n)], } \\
\text { değilse 0 }\end{array}$ \\
\hline Sans Uyuşması & MIN [N(n), N(m), H(m), M(m)] \\
\hline
\end{tabular}

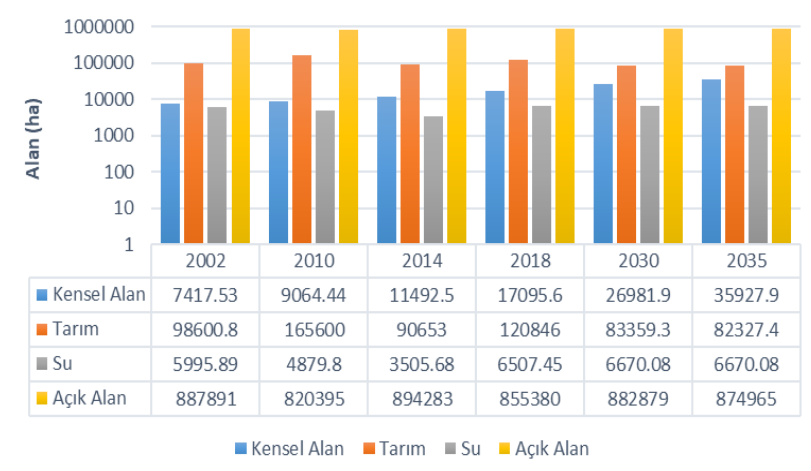

Şekil 8. Mevcut ve tahmin edilen arazi kullanımı (ha)

\section{SONUÇ}

$\mathrm{Bu}$ çalışmada, uzaktan algılama amaçlı uydu sistemleri, CBS teknolojileri ve CA-MC modelleme yaklaşımı, Irak'ın Kerkük ilindeki, 2002-2018 yılları arasındaki kentsel yayılmanın tespiti için kullanılmıştır. Bölgede kentsel alanın, yerleşik arazilerin ve tarım arazilerinin önemli ölçüde arttığı, açık alanların azaldığı tespit edilmiştir. Kentsel arazi gelişimi, ilin farklı bölgelerinde düzensiz bir şekilde gerçekleşmektedir ve bu gelișim ile açık alanların kaybı arasında doğrudan bir ilișki söz konusudur. Arazi kullanımındaki değișim sabit değildir, bu nedenle biri 2002-2010 arasında dönemi kapsayan, diğeri 2010-2018 arasındaki dönemi kapsayan farklı geçiş matrisleri kullanılmıştır. CA-MC modelini kullanmanın bir avantajı, modelin gelecekteki arazi kullanım değişikliklerine yönelik tahminlerin açık bir şekilde yapılmasına imkân tanımasıdır. Öyle ki, bu model ile farklı zaman örneklerinde en az iki arazi kullanım haritasını modellemek sınırlı sayıda veri ile mümkün olmaktadır. Öte yandan, CA-MC Modeli, mevcut durumları yönetmek, kontrol etmek ve gelecekteki talepler için akılcı planlar hazırlamak amacıyla önemli olan biyofiziksel ve sosyoekonomik faktörler gibi kentsel arazi kullanımı değişim faktörlerini analiz edememektedir.

Arazi kullanımı/arazi örtüsü değişikliklerinin tespitinde Landsat verileri genellikle başarılı bir şekilde kullanılmıştır. CBS ile birleștirilmiş dijital görüntü sınıflandırması, hızlı kentleşmenin bir sonucu olarak arazi kullanımı ve arazi örtüsü değişikliklerinin yönü, doğası, oranı ve konumu hakkında kapsamlı bilgi 
sağlama kabiliyetini göstermiştir. Uzaktan algllama sistemleri ile edinilen veriler, uygun maliyetli, çoklu tarihli ve CBS'ye girdi olarak yüklenmeye hazırdır. CBS'nin farklı kaynaklardan gelen mekânsal verileri, farklı formatlar, yapılar, projeksiyonlar veya çözünürlük seviyeleri ile entegre etme kabiliyeti özellikle arazi kullanımı ve arazi örtüsü çalışmalarına büyük yarar sağlamaktadır. Zamansal değişimin ölçülmesi genellikle tarihi haritalar, hava fotoğrafları ve uydu görüntüleri gibi kaynakların kullanılmasına dayanmaktadır. Arazi sınıflarının mekânsal dağılımındaki değişiklikler, farklı tarihlere ait haritaların üst üste bindirilmesi ve mekânsal tesadüflerinin analiz edilmesi ile özetlenebilir. Bir arazi sınıfından diğerine dönüşerek ortaya çıkan değişiklikler, matematiksel olarak, belirli bir pikselin aynı durumda kalması veya başka bir duruma dönüştürülmesi olasılıkları şeklinde tanımlanabilir.

Kentsel arazi kullanımı, bilim ve uygulama açısından zorluk çlkaran karmaşık bir sistem olmasına rağmen, CBS tabanlı kentsel yayılma modellemesi, başka türlü elde edilmesi zor olan gelecekle ilgili nicelleştirilmiş, görselleştirilmiș, mekansal bilgi sağlayabilir. Bu çalıșma sonucunda önemli bulgular elde edilmiştir. Kerkük ilinin, kentsel alanını ikiye katlaması ve önümüzdeki 15 yıl içinde hızlı kentsel yayılma ile karşı karşıya kalması durumunu göstermektedir. Bu arazi değișimi, kaçınılmaz olarak doğal çevre ve ekosistem üzerinde büyük bir baskı oluşturacaktır. 2030 ve 2035 yıllarına ait elde edilen model, çevre bilincini artıracağı umulan iyi veya kötü bir gelecek vizyonu sağlamıștır. Gelecek ile ilgili akıllıca kararlar almak açısından uygun bir bakış açısı sunmaktadır.

\section{ARAŞTIRMACILARIN KATKI ORANI}

Abdullah Fadhil: Literatür taraması, Modelleme, Makale yazımı; Tuba Kurban: Makale yazımı, Düzenleme

\section{ÇATIŞMA BEYANI}

Herhangi bir çıkar çatışması bulunmamaktadır.

\section{KAYNAKÇA}

Avrupa Çevre Ajansı (2006). Kopenhag, Lüksemburg: Avrupa Toplulukları Resmi Yayınlar Ofisi, ISBN: 978-92-9167-370-4.

Al-shalabi M, Billa L, Pradhan B, Mansor S \& AlSharif A A (2013). Modelling urban growth evolution and land-use changes using GIS based cellular automata and SLEUTH models: the case of Sana'a metropolitan city, Yemen. Environmental earth sciences, 70(1), 425-437.

Alsharif A A \& Pradhan B (2014). Urban sprawl analysis of Tripoli Metropolitan city (Libya) using remote sensing data and multivariate logistic regression model. Journal of the Indian Society of Remote Sensing, 42(1), 149-163.

Anderson J R (1976). A land use and land cover classification system for use with remote sensor data (Vol. 964): US Government Printing Office.
Araya Y H \& Cabral P (2010). Analysis and modeling of urban land cover change in Setúbal and Sesimbra, Portugal. Remote Sensing, 2(6), 15491563.

Arsanjani J J, Kainz W \& Mousivand A J (2011). Tracking dynamic land-use change using spatially explicit Markov Chain based on cellular automata: the case of Tehran. International Journal of Image and Data Fusion, 2(4), 329-345.

Atşan H A (2011). Irak'ta nüfus politikası ve 1977 2007 dönemi nüfus artışına etkisi. Kadisiyah sosyal Bilimler, 14(1-2), 347-360.

Barnes K B, Morgan III J M, Roberge M C \& Lowe S (2001). Sprawl development: Its patterns, consequences, and measurement. Towson University, Towson, 1-24.

Başlık S (2008). Dinamik Kentsel Büyüme Modeli: Lojistik Regresyon ve Cellular Automata (İstanbul ve Lizbon Örnekleri). Mimar Sinan Güzel Sanatlar Üniversitesi Fen Bilimleri Enstitüsü.

Bugliarello G (2003). Large urban concentrations: A new phenomenon. Earth Science in the City: A Reader, 56, 7-19.

Carruthers J I \& Ulfarsson G F (2002). Fragmentation and sprawl: Evidence from interregional analysis. Growth and change, 33(3), 312-340.

Coppedge B R, Engle D M \& Fuhlendorf S D (2007). Markov models of land cover dynamics in a southern Great Plains grassland region. Landscape Ecology, 22(9), 1383-1393.

Dadhich P N \& Hanaoka S (2011). Spatio-temporal urban growth modeling of Jaipur, India. Journal of Urban Technology, 18(3), 45-65.

Dai F, Lee C \& Zhang X (2001). GIS-based geoenvironmental evaluation for urban land-use planning: a case study. Engineering geology, 61(4), 257-271.

Fan F, Wang Y \& Wang Z (2008). Temporal and spatial change detecting (1998-2003) and predicting of land use and land cover in Core corridor of Pearl River Delta (China) by using TM and ETM+ images. Environmental monitoring and assessment, 137(1-3), 127.

Forte B, Cerreta M \& De Toro P (2019). The human sustainable city: challenges and perspectives from the habitat agenda: Routledge.

Gordon P \& Richardson H W (1997). Are compact cities a desirable planning goal? Journal of the American planning association, 63(1), 95-106.

Grekousis G, Manetos P \& Photis Y N (2013). Modeling urban evolution using neural networks, fuzzy logic and GIS: The case of the Athens metropolitan area. Cities, 30, 193-203.

Guan D, Li H, Inohae T, Su W, Nagaie T \& Hokao K (2011). Modeling urban land use change by the 
integration of cellular automaton and Markov model. Ecological modelling, 222(20-22), 37613772.

Guerriere M R \& Detsky A S (1991). Neural networks: what are they? : American College of Physicians.

Harris P M \& Ventura S J (1995). The integration of geographic data with remotely sensed imagery to improve classification in an urban area. Photogrammetric engineering and remote sensing, 61(8), 993-998.

Hu Z \& Lo C (2007). Modeling urban growth in Atlanta using logistic regression. Computers, environment and urban systems, 31(6), 667-688.

Jacobs J (1961). The Death and Birth of Great American Cities: London: Penguin.

Jadkowski M A, Howard R R \& Brostuen D E (1990). Application of SPOT data for regional growth analysis and local planning [J]. Photogrammetric engineering and remote sensing, 56(2), 175-180.

Jensen J R (1996). Introductory digital image processing: a remote sensing perspective: Prentice-Hall Inc.

Kahn M E (2000). The environmental impact of suburbanization. Journal of policy analysis and management, 19(4), 569-586.

Kamusoko C, Aniya M, Adi B \& Manjoro M (2009). Rural sustainability under threat in Zimbabwesimulation of future land use/cover changes in the Bindura district based on the Markovcellular automata model. Applied Geography, 29(3), 435-447.

Li X \& Gar-On Yeh A (2004). Data mining of cellular automata's transition rules. International journal of geographical information science, 18(8), 723744.

Liu W \& Seto K C (2008). Using the ART-MMAP neural network to model and predict urban growth: a spatiotemporal data mining approach. Environment and Planning B: Planning and Design, 35(2), 296-317.

Liu X, Li X, Yeh A G-0, He J \& Tao J (2007). Discovery of transition rules for geographical cellular automata by using ant colony optimization. Science in China Series D: Earth Sciences, 50(10), 1578-1588.

Liu X, Liang X, Li X, Xu X, Ou J, Chen Y, ... Pei F. (2017). A future land use simulation model (FLUS) for simulating multiple land use scenarios by coupling human and natural effects. Landscape and Urban Planning, 168, 94-116.

López E, Bocco G, Mendoza M \& Duhau E (2001). Predicting land-cover and land-use change in the urban fringe: a case in Morelia city, Mexico. Landscape and urban planning, 55(4), 271-285.

Méaille R \& Wald L (1990). Using geographical information system and satellite imagery within a numerical simulation of regional urban growth. International Journal of Geographical Information System, 4(4), 445-456.

Muller M R \& Middleton J (1994). A Markov model of land-use change dynamics in the Niagara Region, Ontario, Canada. Landscape Ecology, 9(2), 151-157.

Myint S W \& Wang L (2006). Multicriteria decision approach for land use land cover change using Markov chain analysis and a cellular automata approach. Canadian Journal of Remote Sensing, 32(6), 390-404.

Nechyba T J \& Walsh R P (2004). Urban sprawl. Journal of economic perspectives, 18(4), 177-200.

Osman T, Arima T \& Divigalpitiya P (2016). Measuring urban sprawl patterns in Greater Cairo Metropolitan Region. Journal of the Indian Society of Remote Sensing, 44(2), 287-295.

Ozturk D \& Batuk F (2011). Implementation of GISbased multicriteria decision analysis with VB in ArcGIS. International Journal of Information Technology \& Decision Making, 10(06), 10231042.

Pendall R (1999). Do land-use controls cause sprawl? Environment and Planning B: Planning and Design, 26(4), 555-571.

Pontius Jr R G (2002). Statistical methods to partition effects of quantity and location during comparison of categorical maps at multiple resolutions. Photogrammetric Engineering and Remote Sensing, 68(10), 1041-1050.

Sarı H \& Özşahin E (2016). CORINE Sistemine Göre Tekirdağ İlinin AKAÖ (Arazi Kullanımı/Arazi Örtüsü) Özelliklerinin Analizi/Analysis of LULC (Landuse/Landcover) Characteristics of Tekirdag Province based on the CORINE System. Alınteri Zirai Bilimler Dergisi, 30(1), 13-26.

Seto K C, Fragkias M, Güneralp B \& Reilly M K (2011). A meta-analysis of global urban land expansion. PloS one, 6(8), e23777.

Simmons C (2007). Ecological footprint analysis: $A$ useful method for exploring the interaction between lifestyles and the built environment: London: Routledge.

Staff J R C, Forschungsstelle E K G \& Centre E C J R (2006). Urban sprawl in Europe: The ignored challenge: Office for Official Publications of the European Communities.

Steininger M (1996). Tropical secondary forest regrowth in the Amazon: age, area and change estimation with Thematic Mapper data. International Journal of Remote Sensing, 17(1), 927.

Sudhira H, Ramachandra T \& Jagadish K (2004). Urban sprawl: metrics, dynamics and modelling using GIS. International Journal of Applied Earth Observation and Geoinformation, 5(1), 29-39. 
Sutton P C (2003). A scale-adjusted measure of "urban sprawl" using nighttime satellite imagery. Remote sensing of Environment, 86(3), 353-369.

Triantakonstantis D \& Mountrakis G (2012). Urban growth prediction: a review of computational models and human perceptions.

Tu J V (1996). Advantages and disadvantages of using artificial neural networks versus logistic regression for predicting medical outcomes. Journal of clinical epidemiology, 49(11), 12251231.

Verburg P H, Soepboer W, Veldkamp A, Limpiada R, Espaldon V \& Mastura S S (2002). Modeling the spatial dynamics of regional land use: the CLUES model. Environmental management, 30(3), 391-405.

Verhagen P (2007). Case studies in archaeological predictive modelling (Vol. 14): Amsterdam University Press.

Wakode H B, Baier K, Jha R \& Azzam R (2014). Analysis of urban growth using Landsat TM/ETM data and GIS-a case study of Hyderabad, India. Arabian Journal of Geosciences, 7(1), 109-121.

Wang S, Zheng X \& Zang X (2012). Accuracy assessments of land use change simulation based on Markov-cellular automata model. Procedia Environmental Sciences, 13, 1238-1245.

Wey W (2013). Smart growth principles combined with fuzzy AHP and DEA approach to the transitoriented development (TOD) planning in urban transportation systems. Journal of Energy Technologies and Policy, 3(11), 251-258.

White R \& Engelen G (1993). Cellular automata and fractal urban form: a cellular modelling approach to the evolution of urban land-use patterns. Environment and planning A, 25(8), 1175-1199.

Wu F (2002). Calibration of stochastic cellular automata: the application to rural-urban land conversions. International journal of geographical information science, 16(8), 795818.

Wu H, Li Z, Clarke K C, Shi W, Fang L, Lin A \& Zhou J (2019). Examining the sensitivity of spatial scale in cellular automata Markov chain simulation of land use change. International Journal of Geographical Information Science, 33(5), 10401061.

Xu T, Gao J \& Coco G (2019). Simulation of urban expansion via integrating artificial neural network with Markov chain-cellular automata. International Journal of Geographical Information Science, 33(10), 1960-1983.

Yang X, Zheng X-Q \& Lv L-N (2012). A spatiotemporal model of land use change based on ant colony optimization, Markov chain and cellular automata. Ecological modelling, 233, 1119.

Youssef A M, Pradhan B \& Tarabees E (2011). Integrated evaluation of urban development suitability based on remote sensing and GIS techniques: contribution from the analytic hierarchy process. Arabian Journal of Geosciences, 4(3-4), 463-473.

Zhang Q, Ban Y, Liu J \& Hu Y (2011). Simulation and analysis of urban growth scenarios for the Greater Shanghai Area, China. Computers, Environment and Urban Systems, 35(2), 126-139. 